This item was submitted to Loughborough's Research Repository by the author.

Items in Figshare are protected by copyright, with all rights reserved, unless otherwise indicated.

\title{
Public scholarship and the evidence movement: Understanding and learning from Belgian drug policy development
}

PLEASE CITE THE PUBLISHED VERSION

https://doi.org/10.1177/1477370817731413

\section{PUBLISHER}

(C) The Authors. Published by SAGE

\section{VERSION}

AM (Accepted Manuscript)

\section{PUBLISHER STATEMENT}

This work is made available according to the conditions of the Creative Commons Attribution-NonCommercialNoDerivatives 4.0 International (CC BY-NC-ND 4.0) licence. Full details of this licence are available at: https://creativecommons.org/licenses/by-nc-nd/4.0/

\section{LICENCE}

CC BY-NC-ND 4.0

\section{REPOSITORY RECORD}

Tieberghien, Julie, and Mark Monaghan. 2017. "Public Scholarship and the Evidence Movement: Understanding and Learning from Belgian Drug Policy Development”. Loughborough University. https://hdl.handle.net/2134/25374. 


\title{
Title: Public Scholarship and the Evidence Movement: Understanding and Learning from Belgian Drug Policy Development
}

\begin{abstract}
Debates about public scholarship have gathered momentum in several fields including sociology and criminology. There is much debate over the nature of public scholarship and the forms it can take. In criminology one of the most influential analyses of public scholarship has been developed by Loader and Sparks. For these two thinkers part of the task of scholarship is to contribute to better 'politics'. In their hands, public criminology is close to another long-running analytical trend; research utilisation. The two literatures have for the most part remained separate. This paper puts Loader and Sparks' framework of public scholarship to the empirical test to see if and how it contributes to understanding the role and nature of evidence use in highly sensitive policy areas. We do this through an analysis of recent changes in Belgian drugs policy. We conclude that the framework of Loader and Sparks, although useful in illuminating how publicly engaged scholars can influence and mobilise more open and better informed public and political debate, is hamstrung, by its concentration on the action of individuals in isolation from the complex power structures that underpin the policy process. Synthesising lessons drawn from the research utilisation literature with the work of public criminology provides a potential way forward in understand the role of evidence in policy and also producing 'better' politics in this context.
\end{abstract}

Key words: Public Criminology, drug policy, evidence 


\section{Public Scholarship and the Evidence Movement: Understanding and Learning from Belgian Drug Policy Development}

\section{Introduction}

In the run up to the 2016 referendum on whether Britain should remain within or leave the European Union, Michael Gove, a then Government Minister and leading campaigner for 'Leave', declared with some irony that British people no longer trusted and have 'had enough' of experts (Menon and Portes, 2016). The irony concerned the fact Gove had spent the prior months specifically seeking out the views of experts on penal reform. This episode was the first indication of a 2016 vintage of 'post-truth politics' that encompassed not only the UK's EU referendum, but also the US Presidential Election. In each case, the expert was cast as being at best peripheral to public debate and at worse, an irrelevance. Indeed, in one statement, Gove dismissed the need for research input into policy development, a topic that has been central to two emerging debates across a number of disciplines. The first is the debate that policy should be based on evidence or expertise, which has been considered as common sense particularly since the ideal of evidence-based policy-making gained significant currency in the 1990s (O'Dwyer, 2004; Hughes, 2007). The second, and perhaps broader discussion, concerns the long-standing discussion of what might collectively be termed 'public scholarship' (Foucault, 1972; Barak, 1988; Carrier, 2014; Carlen, 2011; Wacquant, 2011). Notable expressions of public scholarship have taken the form of recent calls for more 'public sociology' (e.g. Burawoy, 2005) and 'public criminology' (Loader and Sparks, 2011) both of which rest on the principle that academic scholarship must apply beyond the academy whether that is through a reconnection with civil society or through more open dialogue between academic and policy communities.

While the evidence-based policy and public scholarship literatures have emerged separately, there is great potential for learning across them and both can contribute to what Loader and Sparks (2011) refer to as a 'better politics' of crime and its regulation. For Loader and Sparks, this is necessary as criminal justice policy making takes place in a hostile environment with the difficulties this entails for rational debate. Such debates are also typical of drugs policy where evidence is harnessed in support or critique of a policy, but often decisions are made with recourse to instinct or ideology (MacGregor, 2011; 2013; Monaghan, 2011; Stevens, 2011). We contend, however, that by using an empirical example of recent Belgian drug policy development we uncover some shortcomings with Loader and Sparks (2011) typology, which can be overcome by drawing on lessons from the research utilisation/evidence-based policy literature.

In this article, we document the trajectory of Belgian drugs policy to critically appraise the application of public criminology - as comprehensively captured by Loader and Sparks' (2011) influential analysis. In doing so we consider and explain the mechanisms through which scientists engage with policy and practice and the roles they take. Whether and how public scholars themselves perceive and handle their public engagements in terms of using evidence has been relatively neglected in discussion of public scholarship (for an exception, see Drake and Walters, 2015). We conclude that Loader and Sparks' typology is a useful tool for mapping the development of policy, but that its focus on the autonomy and capacity of key actors masks the more complex power structures that exist in policy development. We suggest that when synthesised with findings from the longer-established research utilisation literature, a more complex understanding of the interplay between evidence and policy is possible and by association so is a form of 'better politics' in drugs policy and criminal justice. In doing so, the article is organised in the following way. The next section explores in more detail the rise of public criminology illustrating some of its features. We then consider some of the key features of the research utilisation literature. We then use these discussions as a platform to discuss the role of evidence in our chosen case study. Moving on we offer a critical appraisal of Loader and Sparks' (2011) typology before some summarising remarks.

\section{The Rise of Public Criminology}


Debates over public sociology have become the reference point for debates in public scholarship more generally. It is just over 10 years since Michael Burawoy (2005) proclaimed his manifesto for public sociology, drawing on a long tradition stretching back to the very foundation of the discipline of sociology as both Marx and Durkheim could be considered as public intellectuals. In criminology, the role of, and the relationship between, academic criminology and publics outside of the academy has been the subject of much intellectual debate much of which predates Burawoy's intervention (e.g. Foucault, 1972; Barak, 1988; Garland and Sparks, 2000; Carrier, 2014; Carlen, 2011; Wacquant, 2011). The concept of public criminology was first coined by Carrabine, Lee and South (2000), but commentary on the topic gathered apace around 2007 (e.g. Currie, 2007; Chancer and McLaughlin, 2007). Contemporary debates over public criminology are set against the backdrop of an increasing realisation that as criminology has flourished in the academy, its influences on policy development as well as on public knowledge about realities of crime and justice has floundered (Garland and Sparks, 2000; Tonry, 2010; Uggen and Inderbitzin, 2010; Loader and Sparks, 2011). In other words, as Daems, (2008; p.241) notes, 'in times as ours when 'crime talk' flourishes, its voice seems - somehow, somewhere - to get lost'. Loader and Sparks (2011) refer to this as criminology's 'successful failure'.

Discussions over the public function of criminology are varied. For some, the 'public' role of scholarship involves promoting criminological ideas through mainstream media (e.g. Barak, 2007; Wilson and Groombridge, 2010). For others, public scholarship is trying to push the theoretical boundaries of the discipline to create new rendezvous points and theoretical insights (e.g. Zedner, 2007; Hall and Winlow, 2015). An alternative position - and one that perhaps best resembles the mainstream of what public criminology entails - is where academics cross the policy threshold, taking up roles within government or other state agencies (e.g. Stanko, 2007). It is with this latter position that Loader and Sparks (2011) have developed their understanding of public criminology. For Loader and Sparks (2011), the charged atmosphere in which criminal-justice policy discussions take place has led to a concomitant 'heating up' of the relationship between science and policy over the past few decades adding to the combustible policy context of successful failure. This does, however, present an opportunity for scholars. Under such conditions, key actors can add 'coolant' to the debate mainly by engaging in traditional scholarship: these include scientific experts, policy advisors and the observer-turned-players, but by contrast some add further heat mainly through organic means: the social movement theorist/activist and the lonely prophet. Table 1 considers the different modes of scholarly engagement in the criminal justice policy process.

Table 1: Typology of modes of criminological engagement (adopted from Loader and Sparks, 2011)

\begin{tabular}{ll} 
Types & Description \\
\hline Scientific expert & $\begin{array}{l}\text { The scientific expert focuses on the production and } \\
\text { dissemination of scientific knowledge and does not go } \\
\text { beyond infrequent participation in formal advisory } \\
\text { structures. The scientific expert uses knowledge and } \\
\text { methodological skills to answer questions of policy- } \\
\text { makers in a nuanced and well-considered way. }\end{array}$ \\
Policy advisor & $\begin{array}{l}\text { The policy advisor does a great part of their research on } \\
\text { (short-term) contracts for the government, and } \\
\text { perceives it as a responsibility to bring scientific } \\
\text { knowledge to policy-makers through formal advisory } \\
\text { structures or even informal contacts (behind the public } \\
\text { scenes) }\end{array}$ \\
Observer-turned player & $\begin{array}{l}\text { The observer-turned player takes up the opportunity to } \\
\text { participate directly to the development of policy (e.g. as }\end{array}$ \\
\hline
\end{tabular}


a representative of a Minister). This type is colloquially described as an expert who is getting his or her hands 'dirty'.

\begin{tabular}{ll}
\hline $\begin{array}{l}\text { Social movement } \\
\text { theorist }\end{array}$ & $\begin{array}{l}\text { The social movement theorist colloquially supports a } \\
\text { critical/alternative discourse placing knowledge and } \\
\text { skills at the service of those who are marginalised. This } \\
\text { type does not go beyond infrequent participation in } \\
\text { formal advisory structures. }\end{array}$ \\
Lonely prophet & $\begin{array}{l}\text { The lonely prophet focuses on theoretical engagement } \\
\text { and the big picture while philosophising about social } \\
\text { changes and movements. This type also does not go } \\
\text { beyond infrequent participation in formal advisory } \\
\text { structures. }\end{array}$ \\
\hline
\end{tabular}

In the typology, positions range from a stance of near complete detachment to positions where one is more firmly involved in the policy apparatus (Deflem, 2005; Chancer and McLaughlin, 2007; Currie, 2007; De Haan, 2008; Carrabine, et al., 2009; Rock, 2014). Loader and Sparks' account of how criminologists understand their craft and position themselves in relation to social and political controversies about crime, has already prompted significant critique (Wacquant, 2011; Daems, 2011; Hammersley, 2013). For instance, Wacquant (2011) notes how these actor-centred perspectives afford little acknowledgement of the structural conditions under which scholarship is produced; that of the neo-liberal university which champions certain kinds of evidence over others and tends to silence the critical discourse of neoliberalism. It is also argued that their account lacks a substantial reflection on the evidence criminologists may bring into the policy process as academics also often seem to rely on extra-scientific means of persuasion which can jeopardise their credibility (Daems, 2011).

Here we pursue an alternative critique putting Loader and Sparks typology to the empirical test to ascertain whether the roles outlined are indeed indicative of those taken by scholars engaging with the policy process. In doing so, we suggest that the typology is incomplete and that to be able to fully comprehend the role of scholarship in policy it is necessary to not only consider what different forms it might take, but also to consider how it happens. In doing so, we offer an evaluation the typology developed by Loader and Sparks by drawing on lessons from political science and the literature of research utilisation and considering the role of evidence and expertise in recent Belgian drug policy developments.

\section{Models of research utilisation: the role and nature of evidence use}

The long-established literature on research utilisation highlights the complex and often difficult nature of the relationship between evidence and policy in that evidence can influence policy, but only in certain ways and under specific circumstances (Laswell, 1951; Caplan, 1979; Weiss, 1979). One hypothesis is the idea of a direct link from evidence to policy which is often presented in the references to 'evidencebased policy'. Another is the view, described as the conceptual or enlightenment model, that evidence can influence policy indirectly by altering the language and perception of policy-makers. Yet the third hypothesis suggests that research utilisation may involve issues of political power (such as political/selective use of scientific knowledge). Table 2 considers these different models of research utilisation.

Table 2: Three-folded typology of research utilisation (adopted from Weiss, 1979) 


\begin{tabular}{ll}
\hline Three-folded typology & Description \\
\hline Instrumental & $\begin{array}{l}\text { This model represents the typical } \\
\text { understanding, a rather static approach, of the } \\
\text { science-policy nexus. It assumes that scientific } \\
\text { knowledge has a direct bearing on policy. }\end{array}$ \\
\hline Enlightenment & A dynamic perspective of the science-policy \\
nexceptual & $\begin{array}{l}\text { knowledge can be conceived as part of the } \\
\text { process of policy-making. Utilisation must be } \\
\text { considered as a series of events or processes } \\
\text { which may (not) lead to a specific } \\
\text { action/decision }\end{array}$ \\
\hline Political/symbolic & $\begin{array}{l}\text { Offering a more strategic approach of research } \\
\text { utilisation, in this model, scientific knowledge is } \\
\text { considered as ammunition for political sides. It } \\
\text { can be used to silence the arguments of the } \\
\text { opposition or to support ideas, which the } \\
\text { policy-makers have already adopted. }\end{array}$ \\
\hline
\end{tabular}

The particular circumstances under which these research utilisation processes may, or may not, occur have been prominent in recent drug policy discussions (Lenton, 2007; Ritter, 2009; Monaghan 2011; 2014 Stevens, 2011; Tieberghien, 2016). These studies show how establishing networks and active (recurrent) engagements with key players inside and outside the policy-making process, as well as participating in fora or committees is central to policy influence. In effect, they demonstrate when and why evidence is used or not used. A point often downplayed in policy analysis (Haynes, et al., 2011). In doing so, they descend the ladder of abstraction to focus on the mechanisms by which influence can occur. It is at this level that they offer insights for public scholarship.

\section{The Case of Belgian Drugs Policy Making (1996-2003)}

The foundations of modern Belgian drug policy were laid down in the first half of the 1990s, although the drug issue entered the legislative framework with Belgian law criminalising certain drugs and drugs possession in 1921. In the mid- 1990s, a 'window of opportunity' (Kingdon, 2002) opened up when a Parliamentary Working group on drugs (1996-1997) was established by the Federal Parliament in order to develop a clear and timely view on all aspects of the Belgian drug phenomenon. The Parliamentary Working Group asked national and international experts, working in all domains of drug policy, to convey their analysis and to give clear recommendations to the Federal Government. After a silent intermezzo between 1997 and 2000, the drug issue re-emerged on the political agenda. The new Belgian Government further elaborated the principles and recommendations of the Parliamentary Working Group (1996-1997) and established the first 'national drug strategy' in 2001. The Federal Drug Policy Note (2001) determined the policy priorities and thus the legislative and prosecution framework. The strategy recommended developing an integrated and integral drug policy, officially replacing a purely criminal approach by a discourse where the drug problem was primarily considered a problem of public health (Federal Government, 2001). As one of the action points of the Federal Drug Policy Note (2001), the Federal Government planned to amend the Belgian Narcotic Drug Law of 1921 and, accordingly, to develop a new Ministerial Circular Letter. The new drug law and the new Ministerial Circular Letter were endorsed just before the 2003 elections. These decisions, together with the election of a new Government (Verhofstadt II Government: a four-party Government with only the 
Flemish and French-speaking liberals and the Flemish and French-speaking socialists in power), marked the closing of the policy window. Both the 2001 drug strategy and the 2003 drug law form the foundations of the Belgian drug policy today.

One of us conducted a (critical) discourse analysis of specially selected newspaper articles and policy documents and interviews with 55 key informants focusing on the years 1996-2003 of Belgian drug policy. Both data collection methods were used in conjunction with one another. The discourse analysis consisted of a detailed and systematic reading of 164 policy documents including formal, publicly available expressions of strategy and statements of intent made by the Federal Government, as well as parliamentary discussions. Media analysis examined a total number of 1,067 Belgian (including Flemish as well as Walloon) newspaper articles. In the case example, policy documents and newspaper articles were collected from online databases, first using general key words like 'drugs', 'drug use', 'substance use', but eventually refined keywords such as 'drug policy', 'Parliamentary Working Group Drugs', 'Federal Drug Policy Note', and 'drug/cannabis law reform'.

In both cases, Fairclough's (2003) methodological framework was employed. Proven to be useful for the analysis of policy and media documents, the central focus of the framework is on examining how texts draw upon, incorporate, (re)contextualise and dialogue with other texts (so-called 'intertextuality'). Analysis particularly focused on the textual elements that characterise (differences between) discourses, how key policy players are represented in the text and from which perspective, how scientific knowledge and particular scientists were represented, the relationship of scientific knowledge to other forms of information available, and how this was related to the various types of research utilisation and public scholarship. The work in collecting and analysing the policy and media documents was completed between July 2011 and October 2012. Discourse analysis is always a matter of interpretation, especially because it depends entirely on the cogency of a researcher's arguments and/or bilingual abilities. Therefore, additionally, between January and December 2013 fifty-five semistructured interviews with policy-makers (33), scientists (6), journalists (6), professionals (6) and members of interest groups (4) were conducted to better understand the interactions between multiple actors, contextual developments, informal initiatives, networks, conflicts and strategies. Each of these key players was selected on the basis of their knowledge, experience and position within the case. The interview schedule covered key themes such as the respondent's perception of their role in the policy process and particular position in the debate (related to research utilisation and/or policy development), their opinions about the roles played by scientific knowledge and scientists, ideological/political motives, media and interest groups in the parliamentary and governmental debates, and their general perception about the evidence-based/evidence-informed characteristics of the development of Belgian drug policy. Entering the worlds of those involved in the debate and engaging them in an interview is seen as an appropriate way to the understanding of the research utilisation and public scholarship process (Trostle, et al., 1999) and to understand techniques of engaging with policy.

\section{Understanding and Explaining the Role of Public Scholarship}

Within the 'hot' climate in which the development of Belgian drug policy development (1996-2003) unfolded, scientists performed a variety of public roles. Consistent with Loader and Sparks, we noted public engagements as scientific experts, policy advisors, observer-turned players, or social movement theorists/activists. Lonely prophets were notable for their absence, although when discussion concern specific policy matters rather than deeper ontological concerns this is not entirely unexpected.

\section{'Cooling devices': scientific experts, policy advisors and observer-turned players}

For some scientists, the most fruitful way to cultivate a rational policy approach is to emphasize scientific credibility and methodological rigour. Their public engagement is restricted to passively disseminating what they know alongside rare participation in formal advisory structures. In particular, 
several scientific experts participated in the Parliamentary Working Group on drugs in 1996 and the Commission of Public Health (discussing the drug law reform) in 2002. In doing so, they carefully replied to questions for information but were not proactively seeking to engage outside these formal advisory structures (they considered this a 'red line' not to cross):

\begin{abstract}
"My contribution was for the most part illustrative, I gave some additional information. That's it [...] I was not searching for participation, I did not make an effort. I always try to formulate clear recommendations. Maybe this is not good enough and maybe I should participate in the policy-making process. The question is then, to what extent is your scientific research compromised or does one have the impression it is compromised?" (Respondent 24, scientist).

"I just presented some facts, data and that is it [...] They asked me as an expert. I do not take the initiative myself to get involved actively. That is not my goal as an academic." (Respondent 13, scientist).
\end{abstract}

Clearly, in this position most tensions remain between the public role and the academic position with often competing audiences and expectations. While this form of engagement entails minimal involvement in the policy-making process, those scientific experts have sought to influence the policymaking process in a light touch way through the dissemination of data and interpretations. This is in accordance with the conceptual or 'enlightenment' model of research utilisation where scientific knowledge can be conceived as part of the process of policy-making (e.g. in the percolation of new ideas) (Weiss, 1979; Nutley, 2003). For instance, in the PWG (1996-1997), scientific experts stimulated thorough discussion and reflection among policy-makers, leading to the first steps in changing the policy discourse in Belgium. By repeatedly referring to the policy-funded study of De Ruyver, et al. (1992; Poverty, drug use and criminality) and the study of Vercaigne and Walgrave (1995; Youth between (sub)cultures and business: a study focusing on discotheques, house music and nuisance), the contributions of the so-called scientific experts served as strong scientific support for, respectively, the argument that (problematic) drug users in the criminal justice system had to be oriented more towards treatment, and the argument that prevention initiatives have to pay special attention to youth, smart drugs and the consequences of drug use for road safety. As a result, the report of the PWG and its bibliography provided a clear and careful integration of most of the good practices and recommendations. Likewise, although the parliamentary debate about the Belgian drug law in the Commission of Public Health (2002-2003) largely focused on juridical-technical issues, the contributions of several scientific experts sensitised MPs to 'new' scientific knowledge focusing on the dangers of cannabis (e.g. the increasing level of THC, the connection between cannabis use and psychiatric disorders). In offering strong support to arguments against the advocates of a liberal policy, the correlation between early and regular cannabis use and the risk of developing schizophrenia, depression or other psychotic disorders featured increasingly in many parliamentary discussions from 2002-2003 onwards (Hand. Kamer 2001-2002, 21 februari 2002, 208, 32-33; Hand. Senaat 2001-2002, 19 maart 2002, 2-51, 2692).

While still keeping a firm distinction between scientific research and giving advice to policy-makers, policy advisors attach more importance to informing the policy-making process actively. In doing so, some scientists pointed at their public engagements in providing evidence to formal advisory structures, advising MPs or Ministers informally (e.g. through the attendance of study groups of political parties) and establishing contacts with professionals (e.g. police, outreach workers, ...) in order to influence the policy-making process rather indirectly.

"First, I tried to influence the highest level of the policy-making process but that was not successful. It is better to work bottom-up, talking with professionals and MPs in order to climb up. I also have found other ways to distribute information and get involved, I have attended a lot of conferences, participated in study groups, etc. That is the role of a 
scientist. Of course, I understand that some scientists do not do this [...] Eventually, I played a role" (Respondent 52, scientist).

"A study group of a political party is totally different from participating in a formal advisory structure. For instance, in the PWG, an expert had less influence. Each scientist gives a presentation and answers questions. Taking part in a study group allows the expert participate in the development of a party policy on drug policy" (Respondent 47, scientist).

Indicative of the importance attached to establishing good contacts with policy-makers and professionals, is the initiative from a policy advisor who picked up the growing need to develop a comprehensive national drug policy in Belgium. From 1993, an annual conference 'Drug policy 2000' was organised in order to develop and stimulate the interaction between practice, science and policy (De Ruyver, et al., 1995). During these national conferences several drug-related topics were discussed, clearly following the main interests of the media, professionals and policy-makers. The conference was attended by several actors (policy-makers, scientists, practitioners, journalists) which made it possible to stimulate debate about (different) ideas as well as cooperation between (Dutch-speaking and French-speaking) practitioners, scientists, policy-makers and journalists. These important and highly attended conferences set and kept this particular issue high on the political and public/media agenda.

"Those conferences were the mecca of politicians, scientists and practitioners. It was a kind of movement of people who had finally found each other. The conferences also gave a lot of input to the debate in the Parliamentary Working Group on drugs as it can be considered as a sort of prolongation of these debates." (Respondent 9, practitioner).

Of course not all engagement is 'public'. Much lobbying, discussion and persuasion takes place behind the stage, but this can be seen as a (successful) route to be known as experts in the particular field by policy-makers and to establish an interaction between science and policy. Policy advisors allowed for a flow of scientific information to the policy-making process. Not only the annual conferences indirectly encouraged a greater role of scientific knowledge in the policy-making process, but this type of engagement also resulted in policy advisors doing a large part of their research on (short-term) contracts for the Government, a type of research which appears to be particularly attractive to policymakers. For example, the policy-funded inventory of the drug research in Belgium and its neighbouring countries like the Netherlands, Great Britain and France (Van Daele, et al., 1996) was frequently mentioned in the PWG and was used to describe the percentages of cannabis and ecstasy use and drugrelated crimes in parliamentary questions or interpellations. As another example, due to his proactive and long-term involvement as policy advisor in the drug policy-making process (e.g. PWG or policyfunded research), scientist Isidore Pelc was appointed President of the Drug Health Policy Cell, a supporting working cell of the General Drugs Policy Cell. In Belgium, it is the General Drugs Policy Cell who prepares the policy decisions of the Ministers involved in the field of drugs. As a result, in the development of the drug law reform (2003), the Drug Health Policy Cell discussed some preliminary policy documents (bill, Royal Decree, Cooperation agreement, etc.) and eventually formulated some advice which was inspired by scientific knowledge indirectly (Cel Gezondheidsbeleid Drugs, 2002, p.17).

One scientist, Brice De Ruyver, considered it more useful to try to influence policy and secure greater influence for scientific knowledge from the 'inside'. It has been put forward that most scientists often do not have any idea of how policy-making works or how to produce scientific knowledge that stands a chance of influencing policy-makers (Cairney, 2016). Only from the 'inside' scientists are able to discover how the process works and what exerts some influence. In this way, for Loader and Sparks, the scientist becomes an observer-turned player,

"Many scientists do not have a good idea of how the policy-making process works or how scientific knowledge may have any influence [...] Even those who are rarely engaged expect policy-makers to implement what they recommend. Wrong, you need to know how politics works" (Respondent 50, scientist). 
Several examples show how an observer-turned player took up the opportunity to participate directly to the development of Belgian drug policy and how successful this was in the light of research utilisation. First of all, scientist Brice De Ruyver adopted an active engagement in the parliamentary debates. In particular, as a consequence of his expertise and networks (due to the organisation of the national conferences 'Drug Policy 2000'), he was appointed by the PWG as 'external expert' to integrate the findings from the expert hearings into a report and, secondly, to write a draft of the final conclusions and recommendations. In this sense, he acted as a kind of knowledge broker. This draft served as a starting point in the political discussion about Belgian drug policy among the members of the PWG. Altering the tone of the political discussion, the report produced a clear expression of the social and health discourse with the emergence of the harm reduction movement instead of a strict repressive discourse. However, simultaneously, the report already offered and tailored advice in accordance with the preferences of the policy-makers. Clearly, as the members of the PWG aimed to have a sufficient base for policy debate, the observer-turned player could not retain his autonomy/neutrality completely in writing the summarising report. As suggested by Loader and Sparks (2011), this type of public engagement can be described as a role where the expert is getting his or her hands 'dirty', addressing the very thin line between being neutral/external expert or a policy-advocating expert.

Second, the evidence-based policy discourse and movement, despite its criticisms, has given scientists a more overt and direct role in Belgian drug policy-making at the governmental level. In 1999, the Verhofstadt I Government underlined that scientific knowledge was an important resource in policymaking. As a result, uniquely in the Belgian context, Brice De Ruyver became the security advisor to Prime Minister Guy Verhofstadt. It became clear that this type of public engagement meaningfully impacts upon and shapes policy. In particular, this role enabled the observer-turned player to promote the instrumental utilisation of his own scientific research and that of others in the political arena. The instrumental view assumes that scientific knowledge has a direct bearing on policy (Weiss, 1979; Nutley, 2003). As a clear example, the evaluation study 'Belgian drug policy in the year 2000: state of the art 3 years after the recommendations of the PWG' (De Ruyver, et al., 2000) inspired the Federal Drug Policy Note (Federal Government, 2001).

"The report of the PWG and the evaluation study were used [...] The Federal Drug Policy Note had to be in accordance with these documents [...] We did not have to start 'from scratch [...] Working at the governmental level is special: the aim is to unite the representatives of the Ministers and to decide" (Respondent 50, scientist).

On the one hand, the second part of the Federal Drug Policy Note (p.14-31) described the main conclusions of the evaluation study conducted by De Ruyver and colleagues (De Ruyver, et al., 2000). This detailed the actual state of the drug problem and capturing recommendations of the PWG that had already been implemented by the time the policy was created. On the other hand, the recommendations of the evaluation study were influential in determining the specific policy actions by the Federal Government (third part Federal Drug Policy Note, p.31-68). For instance, the evaluation report stressed that, in order to finally realise an integral and integrated drug policy with a vertical and a horizontal policy coordination, "the establishment of a General Drugs Policy Cell must be considered as necessary and crucial" (De Ruyver, et al., 2000, p.8). Accordingly, the establishment of a General Drugs Policy Cell was one of the most important action points of the Federal Drug Policy Note in pursuing a global and integrated approach (Federal Government, 2001a, p.31). As a second example, inspired by the particular recommendations of the evaluation study regarding the problem of driving under the influence of illegal drugs and medication (De Ruyver, et al., 2000, p.13-15, 23), the Federal Drug Policy Note included a number of actions (e.g. prevention campaigns, implementation of drug tests, etc.) (Federal Government, 2001a, p.43). Also the persistent concern about the lack of reliable numbers or registrations and the lack of (funding for) epidemiological studies on drug use was reemphasised in the evaluation study (De Ruyver, et al., 2000, p.20-21). In the Federal Drug Policy Note, the Federal Government eventually demonstrated commitment and responsiveness: e.g. by means of 
establishing a research programme supporting decision-making in the field of illegal drugs (Federal Government, 2001a, p.37-41).

In a similar vein, Brice De Ruyver promoted the instrumental utilisation of other (international) scientific research. Taking into account that policy-makers are also responsible for the international aspects of their policy competences, several national and international drug policy studies (with special attention to the cannabis policy) were compared (Federal Government, 2001, p.57-58). As a result, the analysis of drug policies in other European countries (the Netherlands, France, Germany, Luxembourg, the United Kingdom), included in the attachment of the Federal Drug Policy Note, was very much a result of the promotion by this observer-turned player, as outlined by policy personnel involved at the time:

"I remember that we took into account some international studies of drug policies in European countries and the prevalence rates provided by the EMCDDA. Brice De Ruyver joined the Inter-Cabinet Working Group to stimulate the debate. He also urged more scientific support." (Respondent 20, policy-maker).

"A permanent dialogue with Brice De Ruyver was used to advance the debate regarding the Federal Drug Policy Note. In particular, he kept close contacts with the policy-makers. He had a very large political network. As a policy-maker, I talked with him in order to get a scientific update." (Respondent 34, policy-maker).

With this in mind, such a public role seems by far the most effective means to advance an evidenceinformed drug policy. However, it is important to set realistic expectations about the contributions of scientists in the policy-making process. An observer-turned player is able to inform policy-making, not to make it. Some findings of the evaluation study and international drug policy studies were also used in a more political/symbolic way by policy-makers. In the political/symbolic model of research utilisation, scientific knowledge is considered as ammunition for political sides (Weiss, 1979). For instance, an important recommendation was that the Federal Drug Policy Note had to resolve the lack of uniformity in prosecutions of cannabis possession between different Public Prosecutor's offices. The evaluation study attributed a large part of this problem to rather vague notions such as 'public nuisance', 'problematic use' and 'limited possession for personal (single or occasional) use' (De Ruyver, et al., 2000, p.41). However, there were important shortcomings in the efforts to address this deficiency. Although the Federal Drug Policy Note introduced new definitions, they still remained too blurry and open to interpretation by police officers, prevention workers, social workers and the general public. In other words, in the Federal Drug Policy Note reference was made to the Governments' investment in the research, by way of demonstrating commitment and responsiveness. Nevertheless, the vagueness of these notions was not resolved.

\section{Mobilisation of 'heating' alternatives by social movement theorists}

According to Loader and Sparks (2011), social movement theorists/activists take up a similar role as scientific experts as they primarily aim to produce scientific knowledge and do not go beyond infrequent participation in formal advisory structures. However, they seek to influence in a different manner by acting as a 'heating device' and injecting critical/alternative discourse into debates. Social movement theorists/activists align themselves with social groups whose interests are not served by policy-makers and aim to place knowledge and skills at the service of those who are marginalised or excluded (e.g. drug users).

"As scientists, we have to engage in the movement for the reduction of the harm for drug users by critically addressing the existing presuppositions about drugs in society [...] For instance, most community based drug use is highly 'controlled' [...] and associated with low risk for the large majority of drug users [...] these insights are relevant for policy-makers who are looking for alternatives (Peter Cohen, scientist; Report of the PWG, p.172-185).

In the PWG, issues concerning the largely unproblematic characteristic of drug use, the role of selfcontrol strategies and the legitimacy of the criminalisation of drugs (cannabis in particular) have been 
put forward by several scientists. Those struggle for alternative politics were, however, not successful in impacting upon research utilisation in policy-making. Their insights were used as ammunition in political struggles among MPs (political/symbolic utilisation) but tended to be left unused in actual policy-making. In other words, even though their knowledge was embedded in the policy process, too radical accounts were likely to be excluded (Stevens, 2007). As advocated by Walters (2003), it is clear that some scientific knowledge fits the interests of the powerful groups, while others may not. The choice of what counts as 'usable' scientific knowledge and who is considered authoritative or trustworthy involves acts of power.

"Scientific research is not always usable for policy-makers. For instance, there were some critical voices [...] if there are too many differences in opinion with the leading policymakers, it is difficult to play a role." (Respondent 5, policy-maker).

"It makes no sense to integrate findings that are supporting a totally different view than the view policy-makers want to end with [...] some critical issues indeed have been left out in the final report" (Respondent 4, policy-maker).

Nevertheless, it became clear that social movement theorists/activists can mobilise alternative avenues for the uptake of scientific knowledge. While heating up the political climate, these alternative voices also generated a large public response: a considerable number of newspaper articles covered these accounts and, simultaneously, several interest groups, campaigning for drug user's rights, were vigorous in promoting these ideas and persuading policy-makers through the media and through the organisation of demonstrations. The creation of a powerful counter discourse eventually resulted in the Federal Drug Policy Note (2001) stating that "the Federal Government is an advocate of the need to rethink the international conventions in order to produce a realistic response to cannabis use as well as the establishment of harm reduction initiatives" (p.46, Federal Drug Policy Note). This can be considered an important element of the reframing of Belgian drug policy and one that several stakeholders such as social movement theorists/activists, media and interest groups (with the help of the green parties) had fought to bring about since the PWG.

\section{Discussion}

A focus on the individual actions and capacities of key actors - as put forward by the framework of Loader and Sparks (2011) - is interesting, not least because it informs us about the ways in which scholars can put their body of knowledge to the service of policy-makers alongside other legitimate forms of interests or knowledge. They offer neat and accurate descriptions of the different forms of engagement. However, these stories are incomplete. By drawing on the research utilisation literature, in particular, that which shows how the evidence and policy connection occurs we are able to see how the journey from evidence to policy takes place. In this sense, the longer-established research utilisation literature is useful to obtain a better understanding of the success or impact of public engagement within the framework of the complex power structures that exist in policy development (e.g. Weiss, 1979, Nutley, et al., 2007; Ingold and Monaghan, 2016; MacGregor, et al., 2014).

Drawing on the work of Weiss (1979) and Nutley (2003) we demarcate three main types of research utilisation that cover the direct to indirect scale. While acknowledging that the categories used are less straightforward than they have been portrayed, the influence of the public roles on research utilisation weighted differently and depended on the type of engagement, and the phase of policy development in which they were engaged. The public engagement of scientists in the run up to the Parliamentary Working Group was characterised by awareness raising of ideas and research by scientists embroiled in the process. Scientists described their input as 'giving information' and presenting 'facts' and 'data'. Here there was a suggestion that they did not engage further, but that they as scientists performed an enlightenment function by trying to insert evidence and data into political decision-making. In a similar vein, during the establishment of the national conferences on drug use which brought together scientists, policy makers and other key stakeholders, the impetus was to foster cooperation and the increasing flow of scientific information into the process rather than the outcomes of policy. Again this 
has the hallmarks of the enlightenment and/or conceptual role of evidence in policy. At times where scientists became more involved in the process, there was a shift in the kinds of influence they sought to achieve. The case of Brice De Ruyver is illustrative here. De Ruyver's role in Belgian policy oscillated over the period in question. As the deliberations of the PWG progressed, De Ruyver was co-opted as an external expert to integrate scientific findings into the policy document. At this point there is a subtle shift from conceptual influence to a more direct influence in policy formulation. But this is not as an independent voice. It is more to add scientific weight to a pre-established direction of travel. Here we witness a more political/tactical use of evidence. However, when we consider the role of De Ruyver in the development of the Drug Policy Note, his influence shifts to more instrumental use whereby De Ruyver is described by policy makers as 'stimulating debate' by making sure that politicians and decision-makers took into account 'international studies of drug policies in European countries'. Thus, via central, influential positions within parliament and government, he created a heightened role for evidence in the policymaking process and mobilised more open and better informed debate. Of course proximity to decision-making is not the determinant of kinds of influence in the form of evidence used by scientists. Critics of policy involved in 'heating up' debates similarly employed conceptual uses of evidence to try and shape the debate. This can be seen in attempts by scientists to raise the contentious issue of harm reduction in debates concerning the PWG, which although high-profile, had little impact on the overall policy.

Second, the examples above also demonstrate how the use of evidence is a multifaceted process that involves multiple steps and multiple actors operating within a wider political context, rather than simple interaction between single key actors. The example of the observer-turned player Brice De Ruyver illustrates this account most clearly. While he succeeded in adding some 'coolant' to the heated debate, the 'success' of his public engagement was contingent on the rules of politics and competition. After all, even an observer-turned player, who devotes themselves to problem representation or the introduction of acceptable, feasible alternatives, will only stand a chance of influencing policy when the evidence fits with a pre-established stance and if it has engaged sponsors in policy circles. Evidence use rarely occurs in a linear/instrumental way and is not a product derived exclusively from the scholar's skills or actions to take advantage of the 'windows of opportunity' and heightened levels of attention to policy problems. Policy change or development is driven by a plurality of factors, especially when considering moments of incremental changes. Thus, an emphasis on public scholarship in relation to evidence use is a way to obtain a greater understanding of the place of public criminology in the array of orientations within the profession. The political context makes the practice of public criminology not only difficult but also important. Public engagement can cool the climate by producing creditable evidence about what works and what does not. A thorough understanding of the complexity of the problem is an essential element for an improved policy.

\section{Concluding Remarks}

Public engagement, from a criminological perspective, is not only a debate about whether (social) scientists should try to engage a broader non-academic audience, but why and how scientific knowledge can make effective and intelligible contributions in the policy-making process given the 'hot' climate in which it operates. Loader and Sparks (2011) have developed a typology to illustrate the ways in which engagement can occur. We conclude that it forms a useful part of the explanatory canon. We think, however, that the complexities of the policy process and the role of evidence cannot be explained solely from actor-centric typologies. Synthesising lessons drawn from the research utilisation literature with the work of public criminology provide a potential way forward. In this sense, we have sought to situate the actor within the network of policy-making. The case of Belgian drugs policy offers a useful reminder of the challenges and opportunities of public engagement in what is at bottom an ineluctably political process. Irrespective of the veracity of scientific facts they publish, statements or results that are considered inconsistent or unacceptable are always susceptible to the abasement of those in power. 
The few comparative studies in this field have shown that, in a variety of socio-economic, cultural and political environments, countries may strongly differ in how they do, or do not, value and use scientific research in formulating or shaping policy (Nutley, et al., 2010; Ritter, et al., 2016). Thus, the dynamics of the policy-making processes as well as the roles of the different actors may change over time, across situations, interests and issues. While caution is needed in making generalisations, our narrative provides a platform for future (empirical) considerations on whether and how public engagement meaningfully impacts upon and shapes research utilisation in policy-making in other countries or other (heavily politicised) policy areas.

Acknowledgements - We would like to acknowledge the comments of the anonymous reviewers for helping to clarify the main points raised in the article.

\section{Bibliography}

Barak, G. (1988). Newsmaking criminology: Reflections of the media, intellectuals, and crime. Justice Quarterly, 5(4), 565-587. doi: 10.1080/07418828800089891

Barak, G. (2007). Doing newsmaking criminology from within the academy. Theoretical Criminology, 11(2), 191-207. doi: 10.1177/1362480607075847

Burawoy, M. (2005). For Public Sociology. American Sociological Review, 70(1), 4-28.

Cairney, P. (2016). The Politics of Evidence Based Policymaking. Basingstoke: Palgrave MacMillan.

Caplan, N. (1979). The two-communities theory and knowledge utilization. American Behavioral Scientist, 22(2), 459-470. doi: 10.1177/000276427902200308

Carlen, P. (2011). Against Evangelism in Academic Criminology: For Criminology as a Scientific Art. In M. Bosworth \& C. Hoyle (Eds). What is Criminology? (pp.95-110). New York: Oxford University Press.

Carrabine, E., Iganski, P., Lee, M., Plummer, K., \& South, N. (2009). Criminology: A Sociological Introduction. London: Routledge.

Carrabine, E., Lee, M., \& South, N. (2000). Social Wrongs and Human Rights in Late Modern Britain: Social Exclusion, Crime Control, and Prospects for a Public Criminology. Social Justice, 27(2), 193-211.

Carrier, N. (2014). On Some Limits and Paradoxes of Academic Orations on Public Criminology, Radical Criminology, 4. Retrieved from: http://journal.radicalcriminology.org/index.php/rc/article/view/33

Cel Gezondheidsbeleid Drugs. (2002). Activiteitenrapport 2002 van de Cel Gezondheidsbeleid Drugs. Brussel: Cel Gezondheidsbeleid Drugs.

Chancer, L., \& McLaughin, E. (2007). Public criminologies: Diverse perspectives on academia and policy. Theoretical Criminology, 11(2), 155-173.

Currie, E. (2007). Against marginality. Arguments for a public criminology. Theoretical Criminology, 11(2), 175-190.

Daems, T. (2008). Making sense of penal change. Oxford: Oxford University Press.

Daems, T. (2011). Public Criminology? Panopticon, 32(2), 105-111.

De Haan, W. J. M. (2008). Publieke criminologie: een criminologie die ertoe doet? Delikt en delinkwent, 10(9), 1051-1060.

De Ruyver, B., Casselman, J., Meuwissen, K., Bullens, F., \& Van Impe, K. (2000). Het Belgisch drugbeleid anno 2000: een stand van zaken drie jaar na de aanbevelingen van de parlementaire werkgroep drugs. Gent: Onderzoeksgroep Drugbeleid, Strafrechtelijk beleid en Internationale criminaliteit. 
De Ruyver, B., Vermeulen, G., De Leenheer, A., \& Van Der Straten Waillet, G. (Eds.). (1995). Op weg naar een geïntegreerd drugbeleid in België? Antwerpen: Maklu.

De Ruyver, B., Vermeulen, G., Franck, P., \& Van Daele, L. (1992). Kansarmoede, druggebruik, criminaliteit. Gent: Universiteit Gent.

Deflem, M. (2005). Public Sociology, Hot Dogs, Apple Pie, and Chevrolet. The Journal of Public and Professional Sociology, 1(1), 4.

Drake D.H. \& Walters, R. (2015). 'Crossing the line': Criminological expertise, policy advice and the 'quarrelling society'. Critical Social Policy, doi: 10.1177/0261018315589448

Fairclough, N. (2003). Analysing discourse. Textual analysis for social research. New York: Taylor and Francis Group.

Federal Government. (2001). Beleidsnota van de Federale Regering in verband met de drugproblematiek [Federal Drug Policy Note]. Brussel: Federale Regering.

Foucault, M. (1972). The Archaeology of Knowledge. London: Routledge.

Garland, D., \& Sparks, R. (2000). Criminology, Social Theory and the Challenge of Our Times. In D. Garland \& R. Sparks (Eds.), Criminology and Social Theory (pp. 1-22). Oxford: Oxford University Press.

Hall, S., \& Winlow, S. (2015). Revitalizing Criminological Theory: Towards a New Ultra-Realism. Routledge.

Hammersley, M. (2013). The myth of research-based policy \& practice. London: Sage.

Hand. Kamer 2001-2002, 21 februari 2002, 208, 32-33

Hand. Senaat 2001-2002, 19 maart 2002, 2-51, 2692

Haynes, A. S., Derrick, G. E., Chapman, S., Redman, S., Hall, W. D., Gillespie, J., \& Sturk, H. (2011). From "our world" to the "real world": exploring the views and behaviour of policy-influential Australian public health researchers. Social Science \& Medicine, 72(7), 1047-1055.

Hughes, C. E. (2007). Evidence-based policy or policy-based evidence? The role of evidence in the development and implementation of the Illicit Drug Diversion Initiative. Drug and Alcohol Review, 26(4), 363-368.

Ingold, J. \& Monaghan, M. (2016) Evidence Translation: An Actor- Centred Approach to Analysing the Evidence to Policy Connection. Policy \& Politics, 44 (2), 171-190

Kingdon, J. W. (2002). Agendas, alternatives and public policies. London: Longmans.

Lasswell, H. D. (1951). The policy orientation. In D. Lerner and H. D. Lasswell (Eds.), The Policy Sciences (pp.3-15). Stanford, CA: Stanford University Press.

Lenton, S. (2007). Beyond modelling and evidence: bridging the gap between drug policy research and drug policy practice. Paper presented at the First Annual Conference of the International Society for the Study of Drug Policy, Oslo.

Loader, I., \& Sparks, R. (2011). Public criminology? New York: Routledge.

MacGregor, S. (2011) 'The impact of research on policy in the drugs field, Methodological Innovations Online, 6 (1) 41-57

MacGregor, S. (2013). Barriers to the influence of evidence on policy: Are politicians the problem? Drugs: Education, Prevention, and Policy, 20(3), 225-233. doi: 10.3109/09687637.2012.754403

MacGregor, S., Singleton, N. \& Trautmann, F. (2014). Towards good governance in drug policy: Evidence, stakeholders and politics. International Journal of Drug Policy, 25(5), 931-934. 
Menon, A. and Portes, J. (2016) 'You're wrong Michael Gove - experts are trusted far more than you, The Guardian, $\quad 9^{\text {th }} \quad J u n e, \quad 2016$ available online at https://www.theguardian.com/commentisfree/2016/jun/09/michael-gove-experts-academics-vote

Monaghan, M. (2011). Evidence versus politics. Exploiting research in UK drug policy making? Bristol: Policy Press.

Monaghan, M. (2014). Drug Policy Governance in the UK: Lessons from changes to and debates concerning the classification of cannabis under the 1971 Misuse of Drugs Act. International Journal of Drug Policy, 25(5), 1025-1030.

Nutley, S. (2003). Bridging the policy/research divide. Reflections and lessons from the UK. Paper presented at the Facing the future: engaging stakeholders and citizens in developing public policy, National Institute of Governance Conference, Canberra.

Nutley, S., Morton, S., Jung, T., \& Boaz, A. (2010). Evidence and policy in six European countries: diverse approaches and common challenges. Evidence \& Policy, 6(2), 131-144. doi: 10.1332/174426410X502275

Nutley, S., Walter, I., \& Davies, H.T.O. (2007). Using evidence: how research can inform public services. Bristol: The Policy Press.

O'Dwyer, L. (2004). A critical review of evidence-based policy making. Melbourne: Australian Housing and Urban Research Institute.

Ritter, A. (2009). How do drug policy makers access research evidence? International Journal of Drug Policy, 20(1), 70-75.

Ritter, A., Livingston, M., Chalmers, J., Berends, L. \& Reuter, P. (2016). Comparative policy analysis for alcohol and drugs: Current state of the field. International Journal of Drug Policy, 31(2), 39-50. doi: 10.1016/j.drugpo.2016.02.004

Rock, P. (2014). The public faces of public criminology. Criminology and Criminal Justice, 14(4), 412-433.

Stanko, B. A. (2007). From academia to policy making Changing police responses to violence against women. Theoretical Criminology, 11(2), 209-219.

Stevens, A. (2007). Survival of the ideas that fit: an evolutionary analogy for the use of evidence in policy. Social Policy \& Society, 6(1), 25-35. doi: 10.1017/S1474746406003319

Stevens, A. (2011). Drugs Crime and Public Health: The Political Economy of Drug Policy. London: Routledge.

Tieberghien, J. (2016). Challenges and opportunities of 'good governance' for drug policy: the case of the development of Belgian drug policy between 1996 and 2003. Drugs: Education, Prevention and Policy. doi: 0.1080/09687637.2016.1230594

Tonry, M. (2010). "Public criminology" and evidence-based policy. Criminology \& Public Policy, 9(4), 783-797.

Trostle, J., Bronfman, M., \& Langer, A. (1999). How do researchers influence decision-makers? Case studies of Mexican policies. Health Policy and Planning, 14(2), 103-114.

Uggen, C., \& Inderbitzin, M. (2010). “Public Criminologies". Criminology \& Public Policy, 9(4), 725-750.

Van Daele, L., Casselman, J., De Baut, D., De Ruyver, B., Etienne, M., Gillet, I., Noirfalise, A. \& Passchyn, L. (1996). Verzameling en beschikbaarheid van epidemiologische gegevens omtrent het gebruik van drugs in België en in enkele buurlanden. Een voorbereidende studie. Brussel: Diensten van de Eerste Minister en Federale Diensten voor Wetenschappelijke, Technische en Culturele aangelegenheden. 
Vercaigne, C., \& Walgrave, L. (1995). Jeugd tussen (sub)cultuur en business: een onderzoek naar megadancings, house en de last van recreatie. Leuven: Acco.

Wacquant, L. (2011). From 'Public criminology' to the reflexive sociology of criminological production and consumption. British Journal of Criminology, 51(2), 438-448.

Walters, R. (2003). Deviant Knowledge. Criminology, politics and policy. Devon: Willan Publishing.

Weiss, C. H. (1979). The many meanings of research utilization. Public Administration Review, 39(5), 426-431.

Wilson, D., \& Groombridge, N. (2010). 'I'm Making a TV Programme Here!': Reality TV'S Banged Up and Public Criminology. The Howard Journal of Criminal Justice, 49(1), 1-17.

Zedner, L. (2007). Pre-crime and post-criminology?. Theoretical criminology, 11(2), 261-281. 